\title{
The Implementation of Earmarking Tax Policy on Cigarette Tax in West Java Province
}

\author{
Maisarah Putriyandri Atsani ${ }^{1}$, Murwendah ${ }^{2}$ \\ ${ }^{1}$ Department of Fiscal Administrative Science, Faculty of Administrative Science, \\ Universitas Indonesia (email: maisarahatsani@gmail.com) \\ ${ }^{2}$ Corresponding author. Department of Fiscal Administrative Science, Faculty of Administrative Science, \\ Universitas Indonesia (email: murwendah09@ui.ac.id)
}

\begin{abstract}
In an effort to control cigarette consumption in Indonesia, one of the policies used by the government is the earmarking tax policy on cigarette tax. In fact, the prevalence of smoking in Indonesia continues to increase even though the government has imposed various state levies. The purpose of this study is to analyze the implementation of earmarking tax policy on cigarette tax in West Java Province, as one of the regions receiving the largest cigarette tax allocation in Indonesia. This research uses qualitative approach with data collection techniques of literature and in-depth interviews. The results show that the earmarking tax policy on cigarette tax has not been able to reduce the prevalence of smoking since the cigarette tax in the region has not been utilized as per its designation. The function of control of earmarking tax policy on cigarette tax is limited to controlling budgeting aspect; yet, there is no control function related to cigarette tax income to be used according to its purpose (earmarking). Other factors are the cheap price of cigarettes sustained by people's increasing revenue, massive tobacco advertising, and fervent smoking culture in the community. A partial policy that only relies on state levies is perceived as insufficient to control cigarette consumption, particularly without coordination among stakeholder in central and local governments. In fact, cigarette tax revenue has been budgeted for public health services in West Java Province; nevertheless, its implementation in the field has not been fully utilized for public health services.
\end{abstract}

\section{Keywords:}

cigarette tax; earmarking tax; tax policy implementation; West Java

\section{Introduction}

Tobacco consumption is one of the consumption activities that generate negative externalities related to health issues. World Health Organization (WHO) states that tobacco consumption is one of the main causes of cancer, lung disease, and cardiovascular disease. In addition, tobacco consumption does not only endanger health but may also lead to death. Tobacco consumption can kill more than 7 million people every year; six million deaths are directtobacco-users and approximately 890,000 deaths are passive smokers (WHO, 2017).
Despite the negative externalities caused by tobacco consumption, the number of cigarette consumers in the world is still high. Approximately 5.8 trillion cigarettes were consumed in 2014, and the number is still increasing. Cigarettes are consumed by over 1.1 billion people who smoke tobacco by the year 2015 (WHO, 2016). Indonesia is one of the countries with the highest cigarette consumption in the world. Indonesia ranks fourth with the largest number of cigarette consumption after United States of America, Russia, and China in 2014 (Tobaccoatlas, 
2015). In addition, Indonesia places second in regards to smoking prevalence in Southeast Asia. Indonesia's smoking prevalence (with age standard among people aged 15 years and over) in 2016 amounts to $39.5 \%$, with an average of $24.8 \%$ for the Southeast Asian region and a global average of $21.9 \%$ (WHO, 2016). That is, the large proportion of smokers in Indonesia to the population in the age group over 15 years is $39.5 \%$ and that figure exceeds the average of Southeast Asia, which is only $24.8 \%$ and $21.9 \%$ globally on average.

Based on the impact caused by tobacco, tobacco tax is one of the efforts to control tobacco use. A study states that a significant increase in tobacco taxes is the most effective strategy for controlling tobacco. Then, there is a greater positive impact when some tobacco tax revenues are used to control tobacco, health promotion, health-related activities (Chaloupka et al., 2012).

Even though Indonesia has not ratified The WHO Framework Convention on Tobacco Control (WHO FCTC), which is raising taxes on tobacco, it has become one of the instruments used to control cigarette consumption; Indonesia utilizes tax instruments to do so, among other states; levies in the form of excise, Value Added Tax, and Cigarette Tax. Excise and Value Added Tax are Central Taxes, while Cigarette Tax is Local Tax. In relation to local tax collection, Indonesia has implemented the concept of earmarking tax on Cigarette Tax. According to McCleary, earmarking tax is a government policy utilizing budget for particular programs whose sources of income and expenditure are specifically determined (Sitepu, 2016, p. 5).

The earmarking tax concept on cigarette tax is regulated in Law No. 28/ 2009 on Local Taxes and Local Levies and the Regulation of the Minister of Finance No. 11/2017 on the Third Amendment to the Regulation of the Minister of Finance No. 115/2013 on the Procedures for Collecting and Depositing Cigarette Tax. Based on these regulations, cigarette tax revenue is deposited to the regions by transferring it to the Regional General Cash Account (RKUD) of each province based on the proportion of the population. The distributed cigarette tax revenue is allocated for at least $50 \%$ to fund public health services and law enforcement.

The realization of cigarette tax revenue is the basis for depositing cigarette tax revenue to provincial RKUD as stipulated in the Regulation of the Minister of Finance No. 11/2017 on the Third Amendment to the Regulation of the Minister of Finance No. 115/2013 on the Procedures for Collecting and Depositing Cigarette Tax. The deposit is conducted quarterly in the first month of the next quarter. In addition, the target of revenue from excise on tobacco products is the basis for the Directorate General of Fiscal Balance to determine decisions regarding the proportion and estimation of cigarette tax revenue for each province. Based on the 2018 Fiscal Year, the target of revenue from excise on tobacco products is IDR $148,230,000,000,000$, and it is estimated that $2 \%$ of the revenue is obtained from excise on sliced tobacco that is not an object of cigarette tax. Therefore, the basis for calculating cigarette tax is IDR $145,265,400,000,000$ (98\% of IDR $148,230,000,000,000)$. Thus, the estimated revenue from cigarette tax is $10 \%$ of IDR $145,265,400,000,000$ (Public Relations of the Directorate General of Fiscal Balance, the Ministry of Finance, 2016). Table 1 presents the total estimation of cigarette tax revenue deposited to the 2016-2018 RKUD.

Based on Table 1, the target of revenue from excise on tobacco products has increased in the 2017 APBN and declined in the 2018 APBN. The estimated cigarette tax revenue deposited to RKUD has increased in the 2017 fiscal year from IDR $13,529651,776,000$ to IDR $14,688,044,000,000$, and declined in the 2018 fiscal year from IDR $14,688,044,000,000$ to IDR $14,526,540,000,000$.

Based on the Decree of the Director General of Fiscal Balance on the Proportion and 
Table 1.

Estimated Cigarette Tax Revenue Deposited to the 2016-2018 RKUD

\begin{tabular}{lccc}
\hline & 2016 & 2017 & 2018 \\
\hline $\begin{array}{l}\text { Total estimated cigarette tax } \\
\text { revenue deposited to RKUD }\end{array}$ & $13,529,651,776,000$ & $14,688,044,000,000$ & $14,526,540,000,000$ \\
\hline
\end{tabular}

Source: the Decree of the Director General of Fiscal Balance regarding the proportion and estimation of cigarette tax revenue for the 2016, 2017 and 2018 fiscal years.

Figure 1.

The Estimation of Cigarette Tax Revenue for Each Province in the 2018 Fiscal Year

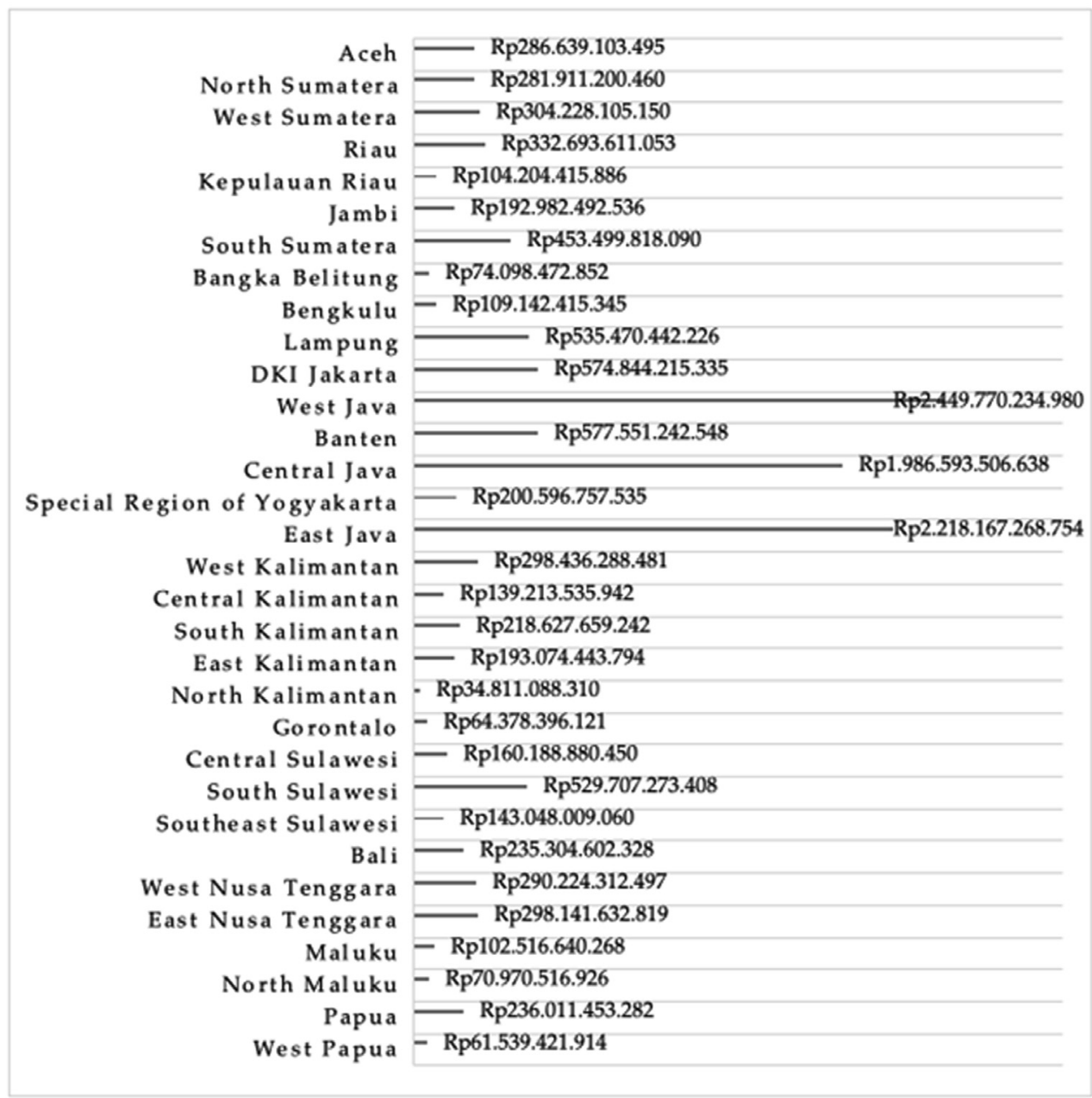

Source: the Decree of the Director General of Fiscal Balance No 53 of 2017 on the Proportion and Estimation of Cigarette Tax Revenue for each Province in the 2018 Fiscal Year (reprocessed by the author).

Estimation of Cigarette Tax Revenue for Each Province in the 2018 Fiscal Year, the highest cigarette tax revenue is obtained by West Java. Furthermore, the largest proportion of cigarette tax revenue is obtained by East Java and Central Java. Figure 1 presents the estimation of cigarette tax revenue deposited to the RKUD of each province in 2018.

It is relevant, considering that West Java has the highest smoking prevalence in Indonesia (population $>10$ years), namely $32 \%$ in 2018 . This figure has not changed 
Figure 2.

Smoking Prevalence (\%) of the Population > 10 Years by Province Year 2018 (Daily and Frequently Smoking)

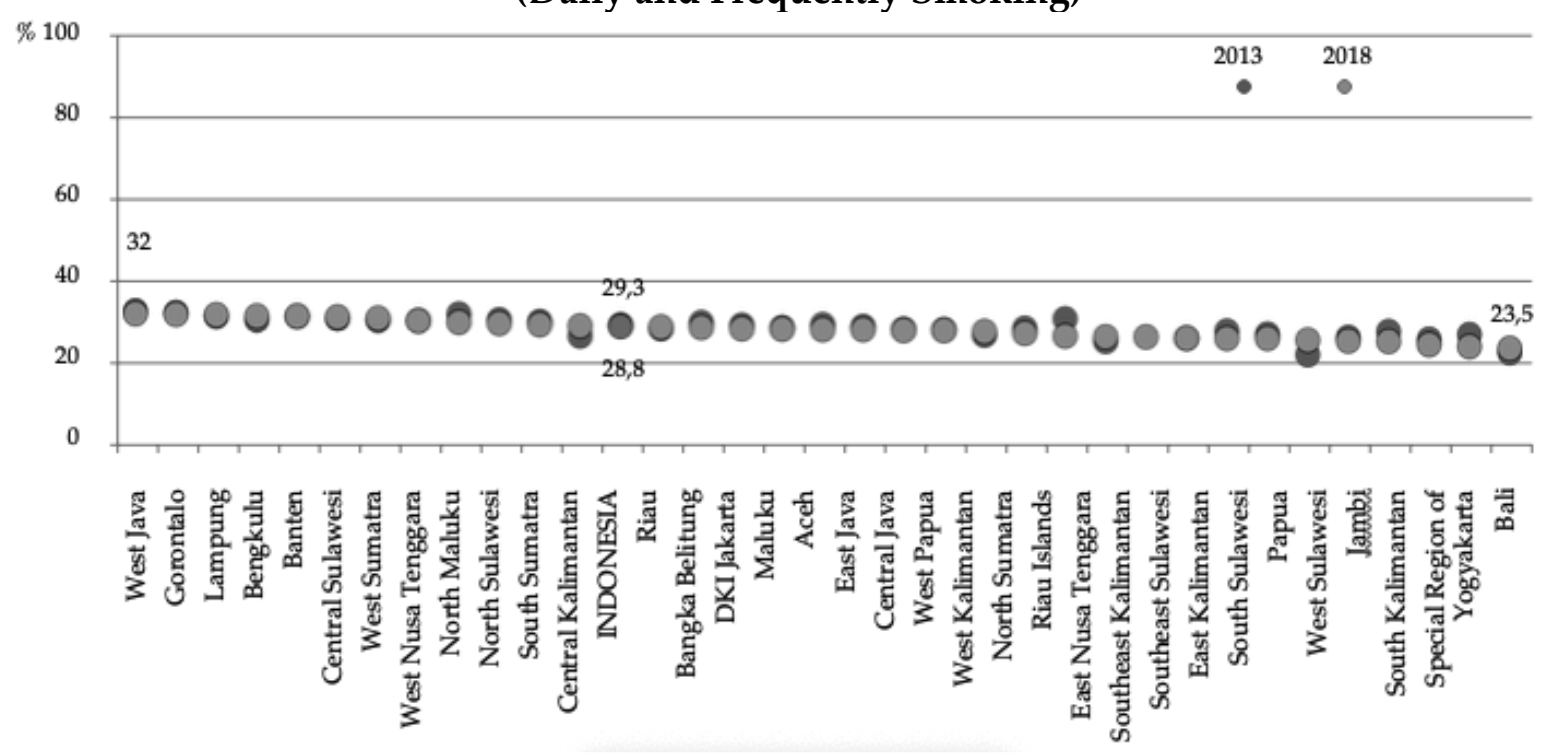

Note: National prevalence is $29.3 \%$ (2013) and $28.8 \%$ (2018)

Source: Riskesdas, 2018

significantly since 2013 and it is constantly above the national smoking prevalence rate, namely $29.3 \%$ in 2013 and $28.8 \%$ in 2018 . Figure 2 shows the percentage of smoking prevalence of population > 10 years by the province in 2013 and 2018.

In detail, the estimated cigarette tax revenue deposited to the West Java is IDR $2,263,754,338,000$ with a proportion of the population of 0.166144 in 2016, IDR $2,462,696,639,000$ with a proportion of the population of 0.167667 in 2017, and IDR $2,449,770,234,989$ with a proportion of the population of 0.168641 in 2018 (Table 2).

Based on the data in Table 2, the proportion of the population of West Java has increased annually. The total estimated deposit of cigarette tax only significantly increases in 2017 but slightly declines in 2018. However, this figure corresponds to the total estimated cigarette tax revenue at the central government level, and West Java obtains nearly $16-17 \%$ of the share of tax cigarette revenue from the total estimated revenue obtained at the central government level. Approximately $70 \%$ of the
Table 2.

Estimated Cigarette Tax Revenue Deposited to the 2016-2018 RKUD in West Java

\begin{tabular}{ccc}
\hline & $\begin{array}{c}\text { Total estimated } \\
\text { deposit }\end{array}$ & $\begin{array}{c}\text { The proportion of } \\
\text { population }\end{array}$ \\
\hline 2016 & IDR & 0.166144 \\
2017 & IDR & 0.167667 \\
2018 & $2,462,696,639,000$ & \\
& IDR & 0.168641 \\
& $2,449,770,234,989$ & \\
\hline
\end{tabular}

Source: the Decree of the Director General of Fiscal Balance regarding the Proportion and Estimation of Cigarette Tax Revenue for the 2016, 2017 and 2018 Fiscal Years

cigarette tax revenue deposited to the RKUD to West Java is deposited to the district or city. Then, at least $50 \%$ of the cigarette tax revenue must be allocated to fund public health services and law enforcement as stipulated in Law No. 8/2009 on Local Taxes and Local Levies.

Essentially, the earmarking tax policy on local tax in Indonesia is extremely required at this time (Inayati, 2016, p. 232). Inayati (2016) adds that the earmarking tax policy is expected 
to encourage expenditure accountability that is able to encourage tax compliance in order to increase local tax revenue, provide the guarantee of funding for certain expenditures, and ensure the implementation of benefit principle in the context of welfare taxation. However, the earmarking tax policy in Indonesia in practice has not been able to encourage fiscal legitimacy due to weak or symbolic earmarking tax and financial management system that is a general fund, raising difficulties in monitoring expenditure allocation of earmarking tax. Therefore, the implementation of the earmarking tax policy on cigarette tax needs to be well considered to ensure that the available fund can be utilized accordingly, responsibly, and transparently.

Few studies have investigated the implementation of earmarking tax policy in Indonesia, including how to evaluate the effectiveness of the policy and criticize the issue of accountability. This study aims to analyze the implementation of the earmarking tax policy on cigarette tax in West Java as the province that gets the largest allocation of cigarette tax revenue. Despite that, the prevalence of smoking in West Java has remained high since 2013 until 2018 as presented in the data in Figure 2. It is hoped that this research will contribute to a deeper understanding of earmarking tax policy implementation in Indonesia in terms of its characteristics, as the symbolic earmarking tax and financial management system that is a general fund.

\section{Theoretical Framework}

In this study, there are several concepts used, namely policy implementation, fiscal policy, earmarking tax, benefit principle, local tax, and piggyback tax. Policy implementation, according to Meter and Horn, is the actions undertaken by individuals or groups or governments to achieve goals based on a policy decision (Purwanto \& Sulistyastuti, 2012, p. 20). Policy implementation is understood through four factors (Edward III, 1980). The first is communication, i.e. channeling instructions to implement the policy. The second is resources, consisting of four types: first, human resources having sufficient numbers and the ability in implementing the policy; second, information on how executors implement a policy, and on the compliance of the persons involved in the implementation of government regulations; third, the authority possessed by each implementer in accordance with its duties; fourth, the facilities used to carry out tasks in order to implement the policy. The third factor is disposition, i.e. the attitude in the form of desire to implement the policy. Such an attitude is influenced by the perspective of the policy implementers. Should the implementers have no desire to implement the policy, they tend to apply discretion in the policy implementation. The last factor is the bureaucratic structure, which has two characteristics, namely: Standard Operating Procedure (SOP) and fragmentation. SOP is a procedure to carry out a work based on certain standards. Fragmentation is the spreading of responsibility in carrying out tasks related to policy implementation.

This study discusses the implementation of earmarking tax policy on cigarette tax in West Java Province. Earmarking is defined as a particular revenue received by a government that is budgeted specifically to finance certain public services (Buchanan, 1963, pp. 457-458). There are several types of earmarking. First, type A, i.e. the source of income comes from a certain tax and the income is used for certain expenditures. Second, type B, i.e. the source of income comes from a certain tax and the income is used for general expenditures. Third, type of $C$, i.e. the source of income comes from the general tax and the income is used for certain expenditures. Fourth, types D, i.e. the source of income comes from the general tax and the income is used for general expenditures (McCleary 1991, pp. 82-83). 
The type of earmarking tax is then grouped into two, namely: substantive earmarking and symbolic earmarking. Substantive earmarking is the revenue allocated to a special fund and is the sole source of funding for a particular expenditure. Symbolic earmarking is the amount of income having no direct impact on the amount of expenditure, and the funds can be included in the general fund (Bird \& Jun, 2005, pp. 7-8). Earmarking is a form of applying benefit principle of taxation (Bird as cited in McCleary, 1991, p. 82). Benefit taxation is a taxation system applied for individuals according to the benefits they receive from public expenditures (Abbasian \& Myles, 2006, p. 1).

With regard to cigarette tax, tax policy is a fiscal policy in the narrow sense, i.e. a policy relating to the determination of taxation base, tax subject, non-tax subject, tax object, the amount of tax payable; or relating to tariff, and the procedure of taxation obligation (Mansury as cited in in Rosdiana \& Irianto, 2013, p. 84). Tax policy has two functions, namely budgeter and regulated functions (Mansury, 1999, p. 2). The budgeter function is Taxes used as a tool to raise funds from the public to finance routine government activities as well as development (Mansury, 1999, p.2). The regulating function is taxes as the government's attempt to regulate and/or change the composition of income and wealth (Mansury, 1999, p. 2).

Cigarette tax in Indonesia is a regional tax. Regional taxes include some types of taxes, i.e. taxes levied by the local government stipulated by Regional Regulation; the taxes levied according to the national regulation whose tariff is determined by the local government; the taxes levied and/or collected by the local government; taxes collected and administered by the central government, yet whose the proceeds are shared and distributed to the local government (Davey as cited in Ikhsan \& Solomo, 2002, p. 75).

Furthermore, the piggyback tax or surcharges tax is an approach to taxation where the regional or local government "piggyback" (or establish a surtax) on an existing higher level of the government tax (Vazquez et al., 2006, p. 125). Based on this definition, piggyback tax is a local tax, which is an additional tax imposed to be administered and collected by the central government. Piggyback tax has three benefits: it allows for centralized control over revenue sources; it gives certainty to local government regarding tax autonomy; and it is simple and can be executed administratively (Vazquez et al., 2006, p.126).

\section{Methods}

The approach of this research is qualitative. According to Cresswell (1994) qualitative approach is inductive thinking that does not begin with theory, since it does not test any theory, but rather to discover new theories that may arise during data collection or analysis (pp. 94-95). This study uses a qualitative approach with descriptive research, describing the context, social setting, or relationship, specifically to explore an issue or explaining why something occurs (Neuman, 2013, pp. 38-39). In the qualitative research, research is conducted to understand the phenomenon of what is experienced by the subject of research, such as behavior, perception, motivation, action, etc., in a holistic manner and by means of descriptions in the form of words and language in a specific context by utilizing various scientific methods. A qualitative approach is chosen as it can provide a holistic picture of a social phenomenon discussed in this study.

The data collection technique used is literature study and field study. The first one is conducted by reading literature related to the topic raised in the study, while the latter is conducted by in-depth interviews. Interviews in field study involve some questions, hearing, interest engagement, and recording of what the informant said; one form of field study interviews is in-depth interview (Neuman, 2013 , p. 407). Regarding the data collection, there are several informants from certain 
institutions interviewed, namely: (1) Head of Sub Division of Excise in Fiscal Policy Agency, (2) Head of Sub Directorate of Evaluation of Regional Revenue in Directorate General of Fiscal Balance of the Ministry of Finance, (3) Head of Sub Directorate of Regional Revenue Region II in Directorate of Regional Finance Administration of the Ministry of Home Affairs (MoHA), (4) Head of Division of Advocacy in Directorate of Health Promotion of the Ministry of Health, (5) Head of Sub Division of Planning in West Java Provincial Health Office, (6) Head of Sub-Directorate of Regional Development Budgeting in West Java Provincial Regional Development Planning Board (Bappeda), and (7) a staff in Office for Management of Regional Revenue, Finance and Assets of West Java Province (BPKAD).

\section{Results and Discussion}

The cigarette tax policy belongs to provincial tax, as stipulated in Law Number 28 Year 2009 on Regional Tax and Regional Retribution concerning Regional Taxes and Levies in Article 2. Under Article 27 of the Law, this cigarette tax is levied by the government institution having the authority to collect duties, i.e. the Directorate General of Customs. Although the Directorate General represents the central government, cigarette tax is still categorized as local tax since, and once collected, it shall be deposited to the regions based on the proportion of population as regulated in Article 27 of Law No. 28/2009 on Regional Tax and Regional Retribution. Perceived from the aforementioned categorization of local taxes by Davey (as cited in Ikhsan \& Solomo, 2002, p.75), cigarette tax in Indonesia is a local tax levied and administered by the central government, i.e. the Directorate General of Customs, yet the cigarette tax revenue is distributed to the provincial government.

The cigarette tax is imposed on excise tax as stipulated in Article 28 and 29 of Law No. 28/2009 on Regional Tax and Regional
Retribution, in which cigarette tax shall be charged at $10 \%$ of cigarette tariff. Therefore, this cigarette is included as piggyback tax as Vazquez (2006) has asserted; piggyback tax is a regional tax, an additional tax on a central and local taxes administered and collected by the central government. Cigarette tax is levied under piggyback tax system in order to ease the administration of its collection. Such ease of administration is existent since the collections of cigarette tax is simultaneous with cigarette excise. Consequently, the local government does not need to collect the tax and pay for its cost. This is in accordance with the benefits of piggyback tax itself as described by Vazquez (2006); piggyback tax is simple and can be implemented administratively.

The tobacco tax policy in Indonesia has an earmarking tax; it is stipulated in Law No. 28/ 2009 on Regional Tax and Regional Retribution in article 31. Under the aforementioned article, at least $50 \%$ of tax revenues is used for public health services and law enforcement. The policy is an earmarking tax policy for the revenues generated and is used specifically to fund public services. This is in accordance with the statement by Buchanan (1963) that earmarking tax is a certain revenue received by the government that is budgeted specifically to finance certain public services. Based on the type of earmarking tax asserted by McCleary (1991, pp. 82-83), the one applied on cigarette tax is included in type $B$, since the source of income comes from a particular revenue, i.e. cigarette tax, and the revenue is used for general expenditures, namely public health services and law enforcement as regulated in Law Number 28 Year 2009 on Regional Tax and Regional Retribution. Public health service is categorized as general expenditure since it is for general disease and not only devoted to diseases caused by cigarette consumption. This can be seen in the Regulation of Ministry of Health No. 53/2017 on the Amendment of the Ministerial Regulation No. 40/2016 on the Technical Guidelines on the Use of Cigarette Tax for the Funding of Public 
Health Services in Article 2 paragraph (1). Based on that Regulation of Ministry of health, cigarette tax revenues are not only related to public health services caused by cigarettes alone, but they can also be used to reduce risk factors for noninfectious and infectious diseases, expand health promotion, improve family health, increase nutrition, enhance health environment, improve occupational health and sports, develop control of cigarette consumption and other tobacco products, health services at first-level healthcare facilities, and the construction or maintenance of health-care facilities, and/or the provision of health equipment in health-care facilities. Apart from that, the use of cigarette tax revenues for law enforcement has not been regulated specifically in Law No. 28/2009 on Regional Tax and Regional Retribution.

In addition, based on the type of earmarking affirmed by Bird \& Jun (2005), the earmarking tax on cigarette tax in Indonesia is included as symbolic earmarking. Symbolic earmarking is a type of earmarking whose amount of receipt has no direct impact on the amount of expenditure, and the revenue from certain tax is included in the general fund. It can be seen in Law No. 17/2003 on State Finance and Regional Regulation of West Java Province No. 12/2008 on the Principles of Regional Financial Management that all regional revenues are included in one account, namely Regional Budget (APBD).

The earmarking tax policy on cigarette tax applies benefit principle of taxation, as asserted by McCleary (1991), since cigarette tax is levied in accordance with the benefits received by the public, i.e. public health services and law enforcement. According to Abbasian and Myles (2006), benefit taxation is the tax imposition to the public according to the benefits they receive from public spending. Since cigarettes can cause various diseases, it is levied to finance public health services. In addition, it is also used for the benefits of law enforcement, related to illegal cigarette.
Cigarette tax is considered to significantly increase the price of cigarettes, thus people will look for cheaper cigarettes i.e. illegal cigarettes. Therefore, cigarette tax is levied because it has benefits to prevent the circulation of illegal cigarettes.

\section{Analysis of Earmarking Tax Policy on Cigarette Tax as an Instrument of Cigarette Consumption Controlling}

The tax policy on cigarettes and its earmarking tax depicts regulatory function since they are one of the government's policies to control cigarette consumption in Indonesia. Nevertheless, the earmarking tax policy on cigarette tax is considered incapable of reducing the smoking prevalence in Indonesia due to several factors. The first factor is cigarette tax in regions has not yet been utilized according to its allocation, i.e. for public health services, according to the in-depth interview with the West Java Provincial Health Office. West Java Province, receiving the largest tax revenue deposit in Indonesia (see Figure 1), has not also utilized the revenues from cigarette tax as has been allocated. The second factor is the controlling function in the region is limited to the amount of allocation; such limited function in the region has not been as large as stipulated in the Law and Regulation of the Ministry of Health.

In the case of West Java Province, West Java Provincial Regional Development Planning Board and Office for Management of Regional Revenue, Finance and Assets of West Java Province as budget teams in the regions only ensure that cigarette tax revenues have been budgeted or allocated at least $50 \%$ for public health services. In addition, MoHA also performs a controlling function on regions, related to budgeting or the allocation of cigarette tax revenues in the regions. In the budgeting process, MoHA controls Regional Budget (APBD). In this case, MoHA only performs the controlling function of budget. 
However, the controlling function to check whether the utilization of cigarette tax revenues has been in accordance with its allocation is not the responsibility of MoHA.

\section{Analysis of the Implementation of Earmarking Tax Policy on Cigarette Tax in West Java Province}

The earmarking tax policy on cigarette tax is stipulated in Law No. 28/2009 on Regional Tax and Regional Retribution and Regulation of Ministry of Health No. 53/2017 on the Amendment of the Ministerial Regulation No. $40 / 2016$ on the Technical Guidelines on the Use of Cigarette Tax for the Funding of Public Health Service. The policy is implemented and further regulated by each region. In West Java Province, the Regional Regulation No. 13/2011 on Local Taxes stipulating the earmarking tax policy on cigarette tax. The contents are similar to the clauses set forth in Law No. 28/2009 on Regional Tax and Regional Retribution.

\section{The Budgeting Process in West Java Province}

The earmarking tax on cigarette tax in Indonesia is symbolic earmarking (Bird \& Jun, 2005 , p. 7-8). The management of state finances as stipulated in Law No. 17/2003 on State Finance and West Java Provincial Regulation No. 12/2008 on the Principles of Regional Financial Management explains that national and local finances are from general fund, i.e. all revenues and expenditures are incorporated into National Budget (APBN) and Regional Budget (APBD). As a consequence, the implementation of earmarking tax policy on cigarette tax is related to the budgeting process for it is linked to government expenditure. Therefore, the implementation of the earmarking tax policy is symbolic, since all receipts and expenditures are mixed and put into APBD.

West Java Province has a Standard Operation Procedure in budgeting process of expenditure, in line with the assertion of Edward III (1980) that each bureaucratic structure consists of Standard Operating Procedure (SOP). Based on West Java Provincial Regulation No. 12/2008 on the Principles of Regional Financial Management, all regional revenues and expenditures are budgeted in APBD. Therefore, the SOP of budgeting in West Java Province is based on Law No. 17/2003 on State Finance, Law No. 23/2014 on Local Government, and Law No. 25/2004 on National Development Planning System.

The budgeting process in West Java Province starts from the making of Provincial Development Work Plan (RKPD) by West Java Provincial Regional Development Planning Board (Bappeda). West Java Provincial Regional Development Planning Board (Bappeda) composes the initial draft of RKPD to serve as a guide for the Head of SKPD (Regional Work Unit) to make its work plan (Renja). Each SKPD submits its program proposals in the form of SKPD's Renja to West Java Provincial Regional Development Planning Board (Bappeda), one of which is a program proposal (Renja) from West Java Provincial Health Office. Then, drafts of RKPD is composed based on SKPD's Renja and the initial draft of RKPD that serve as the material to be discussed in Development Plan Community Consultation (Musrenbang). Based on the results of the Musrenbang, the Head of West Java Provincial Development Planning Board (Bappeda) set the final draft of RKPD and is stipulated by regional head regulations.

Based on West Java Provincial RKPD in 2018 , one of the spending policies is a health function that is budgeted at least $10 \%$ of the budget, including Revenue Sharing Fund (DBH)- Excise from Tobacco (CHT), cigarette tax, Special Allocation Fund (DAK), and others, so that $50 \%$ of cigarette tax revenue for public health services is part of the $10 \%$.

Based on Law No. 23/ 2014 on Local Government, the RKPD becomes the basis for the regional head in drafting the General Budget Policies-Provisional Budget Priorities and Ceilings (KUA-PPAS). KUA and PPAS 
are used as the basis for making Budget Work Plan (RKA) for each SKPD to be submitted to the Regional Assets and Finance Management Agency (BPKAD). BPKAD makes a Financial Note containing details of the funds for each program and activity. BPKAD makes claims regarding the allocation of funds from a local revenue source for certain SKPD programs, such as cigarette tax revenues for public health services. BPKAD looks for a program of West Java Provincial Health Office associated with public health services to allocate the tax revenues to the program. Then, the RKA is approved by the DPRD and Raperda APBD is drafted based on RKA. The Raperda is discussed until it is approved by the House and the Provincial Government of West Java. After that, the Raperda is submitted to Kemendagri to be evaluated by Kemendagri. Kemendagri evaluation results become material for Regional Govt. Budgetary Team (TAPD), including Health Department of West Java Province to fix adjustment, should there be an inappropriate budget. The adjustment is done with SKPDs or related offices. Subsequently, the adjusted Raperda will be set forth as Perda APBD and is submitted back to the Kemendagri to confirm that the Perda in effect is in accordance with Kemendagri's evaluation of the Raperda.

According to the implementation of earmarking tax in West Java, there is fragmentation in the budgeting process. According to Edward III (1980), fragmentation is the spreading of responsibility in implementing the policy. West Java Provincial Health Office is responsible for making Budget Work Plan (RKA SKPD) and Work Plan (Renja). Bappeda receives RKA from all SKPD for making RKPD. After that, BPKAD is responsible for making a financial note by claiming or plotting a source of regional revenue for a particular program. The Ministry of Home Affairs evaluates Raperda ABPD and Perda APBD.

Related to the implementation of earmarking tax policy on cigarette tax, this policy has been socialized by the Ministry of Finance and the Ministry of Health as the Central Government that made the policy. Based on the socialization, West Java Provincial Regional Development Planning Board and BPKAD West Java Province as the budget team has budgeted and allocated more than $50 \%$ tax revenue for health services. It shows that there is a good distribution of instructions communication, as defined by Edward III (1980), required for effective policy implementation. Furthermore, West Java Provincial Regional Development Planning Board and BPKAD, as budget teams in West Java province, have implemented their disposition well by imposing more than $50 \%$ of cigarette tax revenues for health services.

In addition, cigarette tax revenues used for legal enforcement of illegal cigarette is the responsibility of Public Order Enforcers (Satpol $\mathrm{PP})$ in the regions. However, cigarette tax revenues for illegal cigarette law enforcement has not been implemented in terms of budgeting since Satpol PP does not budget any activity or program for illegal cigarette law enforcement. Unfortunately, Satpol PP only recognizes the enforcement of local regulations (Perda) only, due to the lack of socialization. In addition, the regulation on illegal cigarette law enforcement has not been clearly regulated in Law No. 28/2009 on Regional Tax and Regional Retribution. Therefore, BPKAD only allocates budget from cigarette tax revenue of $50 \%$ for health services, even though the Law stipulates allocation for law enforcement. BPKAD is budgeting a minimal share of cigarette tax revenue at least $50 \%$ because public health service is one of the priority programs whose funding must be $10 \%$ of the APBD.

Based on the above argument, Satpol PP is considered 'not doing the disposition well' for not budgeting any activity or program related to law enforcement for illegal cigarettes. As defined by Edward III (1980), disposition is the attitude of the desire to implement the policy. Since Satpol PP does not spare budget 
for law enforcement, BPKAD, as the budget team, takes a discretion to allocate $50 \%$ cigarette tax revenues only for health services. As Edward III (1980) explains, if the instructions for policy implementation are not clearly channeled, it spares space for discretion. In sum, the implementation of the earmarking tax policy on cigarette tax in West Java Province has been budgeted for public health services, yet not for illegal cigarette law enforcement.

\section{Expenditures related to the Earmarking Tax Policy} on Cigarette Tax in West Java Province

West Java Provincial Health Office is claimed not to get funds from the cigarette tax revenues, as reported to the Ministry of Health as the representative of the central government. In other hand, BPKAD argues that it has been allocated at least $50 \%$ for public health services. West Java Provincial Health Office' actually receives the funds, but the funds are not used. It turns out that the Health Office had once organized activities related to the ban on smoking; the activity, nevertheless, became a finding and considered not in compliance to the Decree of the Ministry of Finance (PMK); consequently, the Office did not use the funds. Therefore, West Java Provincial Health Office is considered 'not doing the disposition well' because they did not use the cigarette tax revenue for public health services with preventive and promotional efforts, as Edward III (1980) defined that disposition is the attitude in the form of desire to implement the policy.

According to West Java Provincial Health Office's statement, the Office did not use the funds because they are afraid that the activities against cigarettes are considered non-compliant to PMK. As defined by Edward III (1980), disposition is influenced by the perspective of the policy implementers; if the implementers have no desire to implement the policy, they tend to apply discretion in the policy implementation. In this case, West Java Provincial Health Office has its own perspective - they are afraid to use the funds, and consequently, West Java Provincial Health Office are not doing the disposition, and they apply their own discretion that the funds are not to be used. But, there is a misunderstanding; the PMK in question is not related to cigarette tax because PMK related to cigarette tax only stipulates about the procedure of collection and deposit of cigarette tax as regulated in PMK Number 11 Year 2017. PMK referred to in the interview is PMK No. 222/2017 concerning the Usage, Monitoring, and Evaluation of Tobacco Revenue Sharing Fund, as the PMK regulates that DBH CHT shall be used for health, employment, environment, and other programs.

Hence, West Java Provincial Health Office equalized cigarette tax revenue to $\mathrm{DBH} \mathrm{CHT}$, since so far, they have only received funds without knowing the source of funding. For not receiving clear information regarding the source of funds, the Office considers that the funds received are DBH CHT funds whose funds may not be used for preventive and promotive efforts.

These conditions occurred before the Hospital is taken under the Health Office. Previously, the hospital was taken under the Head of Hospital, i.e. a Regional Apparatus Organization (OPD) of its own. Subsequent to Law No. 23/2014 on Local Government, the Hospital in West Java Province is under the West Java Provincial Health Office since 2017. The Office, therefore, can then use the funds to purchase medical equipment.

\section{Conclusion}

Based on the results of this study, there are several factors causing the incapability of earmarking tax policy on cigarette tax to reduce the prevalence of smoking. These factors are: (1) cigarette tax in regions has not been utilized according to the allocation, that is for health services; (2) The controlling function of earmarking tax policy on cigarette tax is 
only limited to budgeting, not yet contend with the utilization of tax revenues according to its earmarking. In addition, there are other factors considered as the cause of high smoking prevalence in Indonesia, namely (1) the relatively cheap price of cigarettes compared to people's rising income, frequent cigarette advertising, and smoking culture in the community; (2) the increase in current cigarette prices is inefficient in reducing the smoking prevalence, and (3) policies to control cigarette consumption cannot only come from one institution; it requires collaboration between tax policy and non-tax policy

The Implementation of earmarking tax policy on cigarette tax in West Java province has a Standard Operation Procedure in the budgeting process. Budgeting process in West Java Province starts from the making of Provincial Development Work Plan (RKPD), the RKPD becomes the basis for the regional head in drafting the General Budget PoliciesProvisional Budget Priorities and Ceilings (KUA-PPAS), KUA and PPAS are used as the basis for making Budget Work Plan (RKA), Raperda APBD is drafted based on RKA, and the adjusted Raperda will be set forth as Perda APBD. Then, there is fragmentation or the spreading of responsibility in the budgeting process. The West Java Provincial Health Office, Bappeda, BPKAD, and The Ministry of Home Affairs have their own function in the budgeting process and expenditure. Although the implementation in terms of budgeting has SOP and fragmentation, it needs distribution of instructions to implement this policy for effective policy implementation. This policy has been socialized by the Ministry of Finance and the Ministry of Health, but it is lack of socialization. Therefore, the budget team has implemented their disposition well by imposing more than $50 \%$ of cigarette tax revenues for health services, but Satpol PP is considered not doing the disposition well for not budgeting any activity or program related to law enforcement for illegal cigarettes. Therefore, BPKAD, as the budget team, takes discretion to allocate $50 \%$ cigarette tax revenues only for health services. Furthermore, West Java Provincial Health Office is considered 'not doing the disposition to use the funds', and the office tends to apply a discretion that the funds are not used.

In terms of budgeting, the implementation of earmarking tax policy on cigarette tax in West Java province has been allocated at least $50 \%$ for public health services. However, it has not allocated for illegal cigarette law enforcement. Furthermore, in terms of spending, the policy has not been well implemented in West Java Province because the tax revenues have not been used according to its earmarking.

Based on the above conclusions, the following recommendation are proposed: (1) The Ministry of Finance and other Ministries are expected to collaborate to create regulations aimed at controlling cigarette consumption; (2) The central government is expected to ensure that the regions really comprehend the earmarking tax policy on cigarette tax by re-socializing and re-verifying their current understanding of the policy and how they implement it; hence, local governments can actually use cigarette tax revenues according to the law and the central government should ensure the availability of controlling function for spending related to earmarking tax on cigarette tax.

\section{Acknowledgement}

This study is a part of the output of International Indexed Publications for Students' Final Project of Universitas Indonesia (PITTA UI) Grant of 2018 funded by the Directorate of Research and Community Service of Universitas Indonesia.

\section{References}

Abbasian, E., \& Myles, G. D. (2006). Benefit taxation and public good provision. United 
Kingdom: University of Exeter dan Institute for Fiscal Studies.

Bird, R. M., \& Jun, J. (2005). Earmarking in theory and Korean practice. Retrieved from https://www.researchgate.net/ publication/4983772_Earmarking_in_ Theory_and_Korean_Practice

Buchanan, J. M. (1963). The economics of earmarked taxes. Journal of political economy, 71(5), 457-469. doi: $10.1086 / 258794$

Chaloupka, F. J., Yurekli, A., \& Fong, G. T. (2012). Tobacco taxes as a tobacco control strategy. Tobacco control, 21(2), 172-180. doi: 10.1136/tobaccocontrol-2011-050417

Cresswell, J. W. (1994). Research design: Qualitative and quantitative approach. London: Sage Publication Inc.

Edward III, G. C. (1980). Implementing public policy. Washington D.C: Congressional Quarterly Press.

Goodchild, M., Nargis, N., \& d'Espaignet, E. T. (2018). Global economic cost of smoking-attributable diseases. Tobacco Control, 27(1), 58-64. doi: 10.1136/ tobaccocontrol-2016-053305

Government of West Java Provincial. (2008). The Principles of Regional Financial Management (No. 12/2008). Bandung: Government of West Java Provincial.

Ikhsan, M., \& Salomo, R. V. (2002). Keuangan daerah di Indonesia. Jakarta: STIA LAN Press.

Inayati. (2016). Kebijakan earmarking tax pada pajak daerah di Indonesia: Menuju kebijakan pro fiscal legitimacy dan budget flexibility (Unpublished doctoral dissertation). Universitas Indonesia.

Mankiw, N. G., Quah, E., \& Wilson, P. (2012). Pengantar ekonomi mikro. Jakarta: Salemba Empat.

Mansury, R. (1999). Kebijakan fiskal. Jakarta: Yayasan Pengembangan dan Penyebaran Pengetahuan Perpajakan.
Martinez-Vazquez, J., Timofeev, A., \& Boex, J. (2006). Reforming regional-local finance in Russia. USA: The World Bank.

Mccleary, W. (1991). The earmarking of government revenue: A review of some world bank experience. The World Bank Research Observer, 6(1), 81-104. doi:10.1093/wbro/6.1.81

Ministry of Finance of the Republic of Indonesia, The Director General of Fiscal Balance. (2015). The Decree of the Director General of Fiscal Balance on Proportion and Estimation of Cigarette Tax Revenue for Each Province of Fiscal Year 2016 (No.72/PK/2015). Jakarta: Ministry of Finance of the Republic of Indonesia.

Ministry of Finance of the Republic of Indonesia, The Director General of Fiscal Balance. (2016). The Decree of The Director General of Fiscal Balance on Proportion and Estimation of Cigarette Tax Revenue for Each Province of Fiscal Year 2017 (No.37/PK/2016). Jakarta: Ministry of Finance of the Republic of Indonesia.

Ministry of Finance of the Republic of Indonesia, The Director General of Fiscal Balance. (2017). The Decree of The Director General of Fiscal Balance on Proportion and Estimation of Cigarette Tax Revenue for Each Province of Fiscal Year 2018 (No.53/PK/2017). Jakarta: Ministry of Finance of the Republic of Indonesia.

Ministry of Finance of the Republic of Indonesia. (2017). Ministry of Finance Regulation No. 11/2017 on the Third Amandement to the Regulation of The Ministry of Finance No. 115 of 2013 on the Procedures for Collecting and Depositing Cigarette Tax. Jakarta: Ministry of Finance of the Republic of Indonesia

Ministry of Health of the Republic of Indonesia. (2018). Potrait Sehat Indonesia dari Riskesdas 2018. Retrieved from http://www.depkes. go.id/article/view/18110200003/potretsehat-indonesia-dari-riskesdas-2018.html 
Ministry of Health of the Republic of Indonesia. (2017). Ministry of Health Regulation No. 53/2017 on Amendment of Ministry of Health Regulation No. 40/2016 About Technical Guidelines on the Use of Smoking Taxes for the Funding of Public Health Services. Jakarta: Ministry of Health of the Republic of Indonesia.

Neuman, W. L. (2013). Social research method: Qualitative and quantitative approaches ( $7^{\text {th }}$ Edition). United Kingdom: Pearson Education Limited.

President of the Republic of Indonesia. (2009). Regional Tax and Regional Retribution (Law No. 28/2009). Jakarta: President of the Republic of Indonesia.

President of the Republic of Indonesia. (2003). State Finances (Law No. 17/2003). Jakarta: President of the Republic of Indonesia.

President of the Republic of Indonesia. (2014). Local Government (Law No. 23/2014). Jakarta: President of the Republic of Indonesia.

President of the Republic of Indonesia. (2004). National Development Planning System (Law No. 25/2004). Jakarta: President of the Republic of Indonesia.

Purwanto, E. A \& Sulistyastuti, D. R. (2012). Implementasi kebijakan publik: Konsep dan aplikasinya di Indonesia. Yogyakarta: Gava Media.

Rosdiana, H., \& Irianto, E. S. (2013). Pengantar ilmu pajak: Kebijakan dan implementasi di Indonesia. Jakarta: Rajawali Pers.

Sitepu, E. M. (2016). Penerapan earmarking cukai hasil tembakau di Indonesia: Regulasi dan konsep ideal. Kajian Ekonomi dan Keuangan, 20(3), 241-259. doi: 10.31685/kek.v20i3.200

World Health Organization. (2015). Tobacco factsheet. https://doi.org//entity/ mediacentre/factsheets/fs339/en/index. html

World Health Organization. (2016). Earmarked tobacco taxes: Lessons learnt from nine countries. Retrieved from http://www. who.int/tobacco/publications/economics/ earmarked-tobacco-taxes-lesson-ninecountries/en/

World Health Organization. (2016). Country profile: Indonesia. Retrieved from http:// www.who.int/tobacco/economics/ country_profile/idn.pdf

World Health Organization. (2018). Prevalence of tobacco smoking. Retrieved from http:// apps.who.int/gho/data/node.sdg.3-aviz?lang=en 